Article

\title{
Preparation and Functional Identification of a Novel Conotoxin QcMNCL-XIII0.1 from Conus quercinus
}

\author{
Han Zhang ${ }^{1,2,3, *(\mathbb{D})}$, Anwen Liang ${ }^{4}$ and Xinghua Pan ${ }^{1,2,3, * \mathbb{D}}$ \\ 1 Department of Biochemistry and Molecular Biology, School of Basic Medical Sciences, \\ Southern Medical University, Guangzhou 510515, China \\ 2 Guangdong Provincial Key Laboratory of Single Cell Technology and Application, \\ Southern Medical University, Guangzhou 510515, China \\ 3 Guangdong-Hong Kong-Macao Greater Bay Area Center for Brain Science and Brain-Inspired Intelligence, \\ Southern Medical University, Guangzhou 510515, China \\ 4 School of Life Sciences, Sun Yat-Sen University, Guangzhou 510006, China; lianganw@mail2.sysu.edu.cn \\ * Correspondence: zhangh355@mail2.sysu.edu.cn (H.Z.); panvictor@smu.edu.cn (X.P.)
}

Citation: Zhang, H.; Liang, A.; Pan,

$X$. Preparation and Functional

Identification of a Novel Conotoxin QcMNCL-XIII0.1 from Conus quercinus. Toxins 2022, 14, 99. https://doi.org/ $10.3390 /$ toxins 14020099

Received: 13 December 2021

Accepted: 24 January 2022

Published: 26 January 2022

Publisher's Note: MDPI stays neutral with regard to jurisdictional claims in published maps and institutional affiliations.

Copyright: (C) 2022 by the authors. Licensee MDPI, Basel, Switzerland. This article is an open access article distributed under the terms and conditions of the Creative Commons Attribution (CC BY) license (https:// creativecommons.org/licenses/by/ $4.0 /)$.

\begin{abstract}
Conotoxins are tools used by marine Conus snails to hunt and are a significant repository for marine drug research. Conotoxins highly selectively coordinate different subtypes of various ion channels, and a few have been used in pain management. Although more than 8000 conotoxin genes have been found, the biological activity and function of most have not yet been examined. In this report, we selected the toxin gene QCMNCL-XIII0.1 from our previous investigation and studied it in vitro. First, we successfully prepared active recombinant QcMNCL-XIII0.1 using a TrxA (Thioredoxin A)-assisted folding expression vector based on genetic engineering technology. Animal experiments showed that the recombinant QcMNCL-XIII0.1 exhibited nerve conduction inhibition similar to that of pethidine hydrochloride. With flow cytometry combined fluorescent probe Fluo-4 AM, we found that $10 \mathrm{ng} / \mu \mathrm{L}$ recombinant QcMNCL-XIII0.1 inhibited the fluorescence intensity by $31.07 \%$ in the $293 \mathrm{~T}$ cell model transfected with Cav3.1, implying an interaction between $1 \mathrm{G}$ T-type calcium channel protein and recombinant QcMNCL-XIII0.1. This toxin could be an important drug in biomedical research and medicine for pain control.
\end{abstract}

Keywords: Conus; conotoxin; pethidine; $\alpha 1 G$; CACNA1G; T-type calcium channel

Key Contribution: We prepared a novel conotoxin QcMNCL-XIII0.1 from Conus quercinus, which exhibited nerve conduction inhibition similar to that of pethidine hydrochloride. Recombinant QcMNCL-XIII0.1 may interact with the $\alpha 1 G$ T-type calcium channel protein, which suggests that it is a bioactive substance with important potential in analgesia and related fields.

\section{Introduction}

Although hundreds of toxins have been found, very few have been successfully prepared and tested for their nerve-blocking activity [1-3]. The anesthetic effect and the pharmacological activity mainly depend on the specific conotoxin employed [1-3].

The action targets of conotoxin predominantly fall into three categories: (1) voltagegated ion channels, including $\mathrm{Na}^{+}, \mathrm{K}^{+}$, and $\mathrm{Ca}^{2+}$ channels, typified by conotoxin acting on the $\mathrm{K}^{+}$channels K-PVIIA [4]; (2) ligand-gated ion channels, including acetylcholine receptor and serotonin receptor (5-HT3R), exemplified by $\alpha 4 / 7-C T x$ LvIA, which is a new, potent, and selective $\alpha 3 \beta 2 \mathrm{nAChR}$ antagonist [5]; and (3) G-protein-coupled receptors, such as conulotoxin Contulakin-G, which can activate G-protein-coupled angiotensin receptors [6,7]. A single conotoxin molecule often has strong target specificity, can specifically coordinate cell membrane ion channels or receptors, and can even specifically distinguish between different subtypes of receptors [8-13]. Conotoxin highly selectively coordinates different subtypes of various ion channels [14] and ziconotide (sold as Prialt ${ }^{\circledR}$ ) has been 
used in the treatment of pain [15]. There are numerous conotoxins that have been shown preclinically to have an effect (in vitro or in vivo in animal models) [6,16-19].

T-type $\mathrm{Ca}^{2+}$ channels mainly include a single pore-forming $\alpha 1$ subunit and belong to the family of voltage-gated calcium channels (VGCCs), which control calcium ion flux across the cell membrane and are known sites of channel regulation by secondary messengers, drugs, and toxins. Three genes, $C A C N A 1 G, C A C N A 1 H$, and $C A C N A 1 I$, encode for the three T-type channel isoforms Cav3.1 ( $\alpha 1 \mathrm{G})$, Cav3.2 $(\alpha 1 \mathrm{H})$, and Cav3.3 $(\alpha 1 \mathrm{I})$, respectively, in humans [20-22]. The T-type $\mathrm{Ca}^{2+}$ channel belongs to the calcium channel family, which is activated by low voltage, and when current is short and weak, it can be deactivated rapidly $[23,24]$. Due to its small conductance, the T-type $\mathrm{Ca}^{2+}$ channel is thought to be related to pacemaker activity, low threshold calcium peaks, neuronal oscillation and resonance, and rebound pulse discharge [25]. T-type $\mathrm{Ca}^{2+}$ channels exist not only in the heart and smooth muscles but also in many neurons in the central nervous system. The influx of calcium into cells can cause cells to produce a variety of physiological responses [26-29]. In cardiomyocytes and smooth muscle cells, an activated voltage calcium channel and the increase in calcium solute concentration directly lead to cell contraction, which in turn leads to tissue contraction [30,31]. These calcium channel families have been identified to be highly expressed in the brain, the peripheral nervous system, heart, smooth muscles, bones, and the endocrine system [32]. Modulating the activity of alpha1G subtype channels may provide a novel approach for the treatment of allodynia and hyperalgesia $[33,34]$. At present, there are four approved T-type channel modulators, namely ethosuximide (zarontin ${ }^{\circledR}$ ), valproic acid (Depakene ${ }^{\circledR}$ ) and zonizamide (Zonegrans ${ }^{\circledR}$ ), blockers, and L-type channel blockers. These inhibitors all works on $\mathrm{Ca}^{2+}$ channel Cav3.2, while there are few products that work on Cav3.1 regulators [35,36].

Here, based on our previous investigation of Conus quercinus, using a prokaryotic expression vector with TrxA (Thioredoxin A), we successfully constructed a new toxin gene QcMNCL-XIII0.1 (Supplementary Table S3 [37], named Que-2-c57915_g1_5_6), which induced the high expression, purification, detection, and identification of the toxin. By the improved method of bullfrog sciatic nerve bioelectric activity, we defined its biological nerve-blocking activity, and by flow cytometry combined with fluorescent probe Fluo-4 AM, we preliminarily studied the function of QcMNCL-XIII0.1 in the 293T cell model.

\section{Results}

\subsection{Expression, Purification, and Identification of QcMNCL-XIIIO.1}

The sequencing results of the fusion expression plasmid (Figure 1A) were consistent with the expected results (Supplementary Document S1), that is, the reading frame was correct and the resulting protein was full length. The final induction conditions for the expression of the target protein were as follows: when the $\mathrm{OD}_{600}$ was 0.5 at $37^{\circ} \mathrm{C}, \mathrm{IPTG}$ at a final concentration of $0.1 \mathrm{mM}$ was added, the cells were cultured at $18{ }^{\circ} \mathrm{C}$, and protein was induced for $8 \mathrm{~h}$. The total proteins were purified and analyzed before enzymatic digestion. According to the order of peak time, the two peaks were TrxA- $6 \times$ His-QcMNCL-XIIIO. 1 and nontarget peptides (Figure 1B). 
A

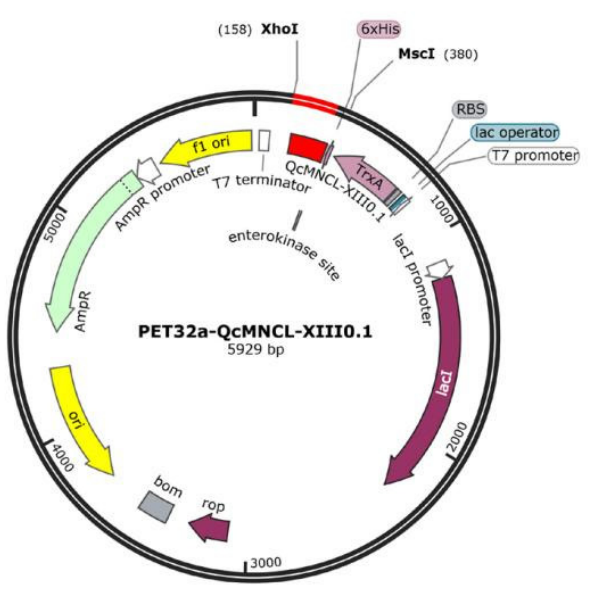

D

D M1 1234456

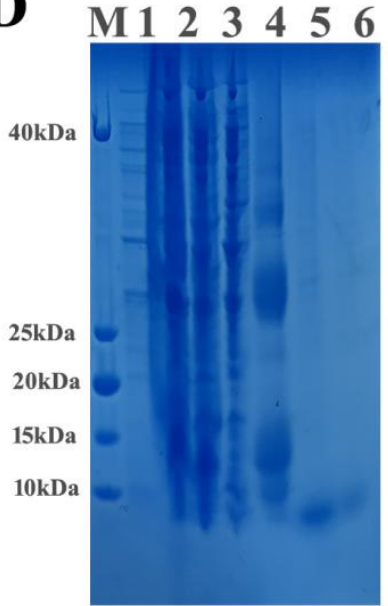

B
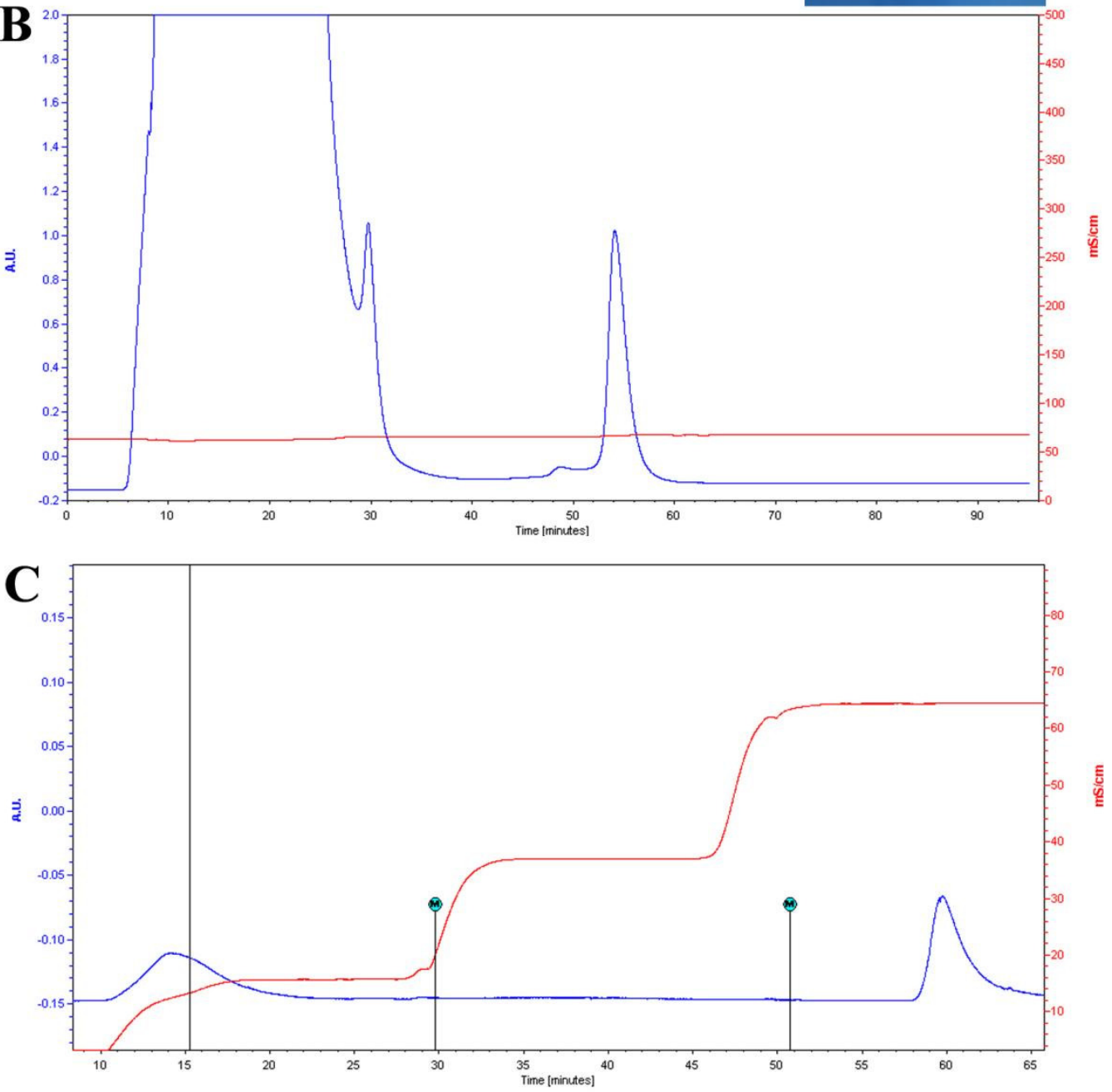

Figure 1. Purification of recombinant QcMNCL-XIII0.1: (A) the expression plasmid PET32aQcMNCL-XIII0.1; (B) $\mathrm{Ni}^{2+}$-chelating sepharose fast-flow chromatography of TrxA-QcMNCL-XIII0.1; (C) $\mathrm{Ni}^{2+}$-chelating sepharose fast-flow chromatography of QcMNCL-XIII0.1; (D) SDS-PAGE analysis recombinant QcMNCL-XIII0.1 expression. M: standard protein marker; 1: uninduced supernatant from BL21 (DE3) cells; 2: T and total protein from BL21 (DE3) cells induced with IPTG; 3: supernatant from BL21 (DE3) cells induced with IPTG after ultrasonification; 4: washed protein from $\mathrm{Ni}^{2+}$-chelating sepharose chromatography in elution buffer; 5 and 6: sample of the fusion protein QcMNCL-XIII0.1. 
After enzyme digestion, affinity purification was again carried out. According to the order of peak time, the two peaks from left to right were QcMNCL-XIII0.1 and a non-target peptide with a $6 \times$ His tag (Figure 1C). SDS-PAGE (sodium dodecyl sulfate polyacrylamide gel electrophoresis) before and after peptide purification is shown in Figure 1D. The amino acid sequence of QcMNCL-XIII0.1 is TMSNLLNFQTRDCPSSCPAVCPNQNECCDGDVCNYSNTLNKYFCIGCGSGGGE. Cysteine amino acids may be connected in many ways within the molecule. The theoretical mass of QcMNCL-XIII0.1 was $5.63 \mathrm{kDa}$, meaning that the molecular weight closely matched the theoretical weight. The QcMNCL-XIII0.1 peptides SNTLNKYFCIGCGSGGGE (Figure 2A), TMSNLLNFQTRD (Figure 2B), and QNECCDGDVCNY (Figure 2C) were also successfully identified by LCMS/MS mass spectrometry.

A

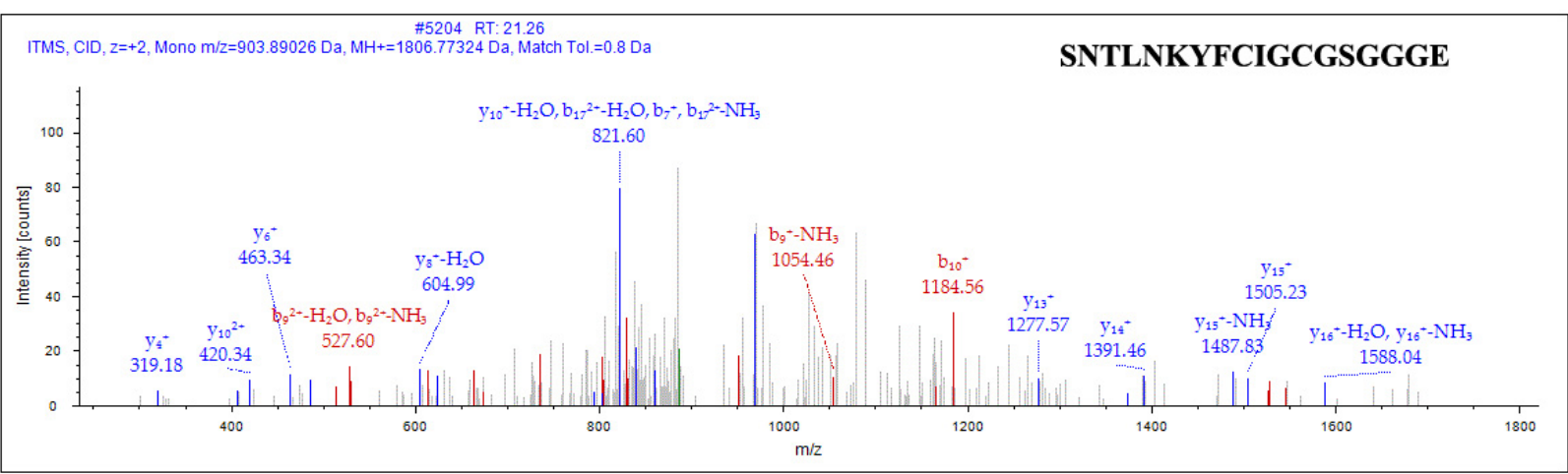

B

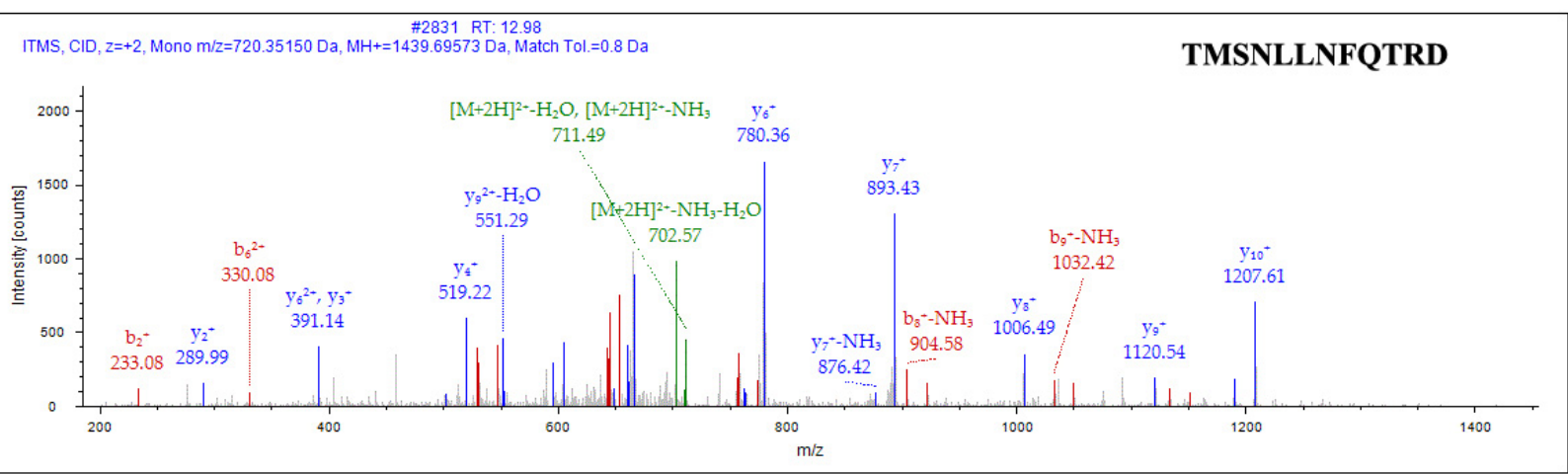

C

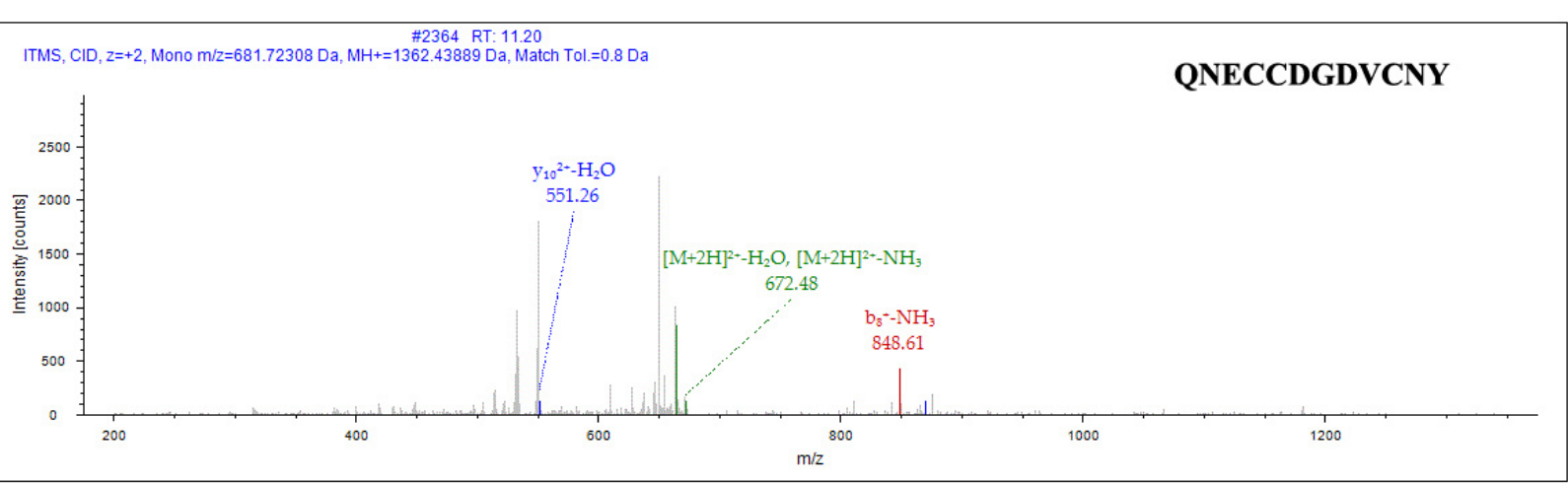

Figure 2. Ion spectrum of QcMNCL-XIII0.1 by LC-MS/MS. (A) Identified sequence of QcMNCL-XIII0.1: SNTLNKYFCIGCGSGGGE; (B) identified sequence of QcMNCL-XIII0.1: TMSNLLNFQTRD; (C) identified sequence of QcMNCL-XIII0.1: QNECCDGDVCNY.

\subsection{The Biological Activity of QcMNCL-XIIIO.1}

We designed a model to test the biological activity of recombinant QcMNCL-XIII0.1, as shown in Figure 6 in another study [37] and as described in the Materials and Methods. We mainly used the BL-420S biological function experimental system (Chengdu Techman 
Software Co.Ltd.) to convert the strength of the frog nerve reflex signal into an electromyography (EMG) signal. According to our experimental model, six electrical stimulations were performed and six signals were collected each time. Each electrical stimulation (each peak) was considered a repeated experimental test. We recorded six electrical stimulation signals before drug administration and six when $1 \mu \mathrm{g} / \mu \mathrm{L}$ recombinant QcMNCL-XIIIO.1 was applied. Based on the statistical methods in the Materials and Methods section, we found that $1 \mu \mathrm{g} / \mu \mathrm{L}$ recombinant QcMNCL-XIIIO.1 inhibited the neural signal transduction by $58 \%$ (Figure $3 \mathrm{~A}$ ). Pethidine was used as a positive control. In our previous investigation, we again found that $5 \mu \mathrm{g} / \mu \mathrm{L}$ pethidine hydrochloride inhibited the neural signal transduction to 85\% (Figure 3B and Supplementary Figure S1). The recombinant QcMNCL-XIII0.1 prepared showed nerve conduction inhibition similar to that of anesthetics.

A
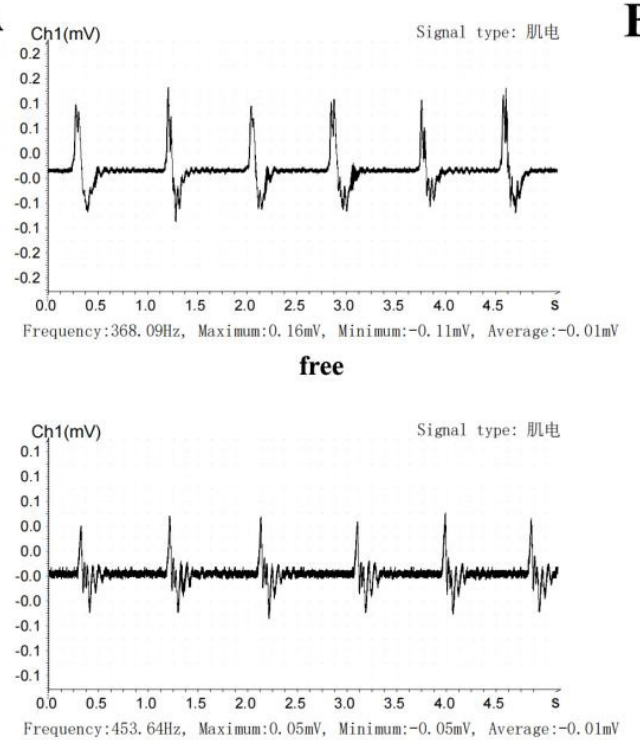

$1 \mu \mathrm{g} / \mu \mathrm{l}$ QcMNCL-XIII0.1
B
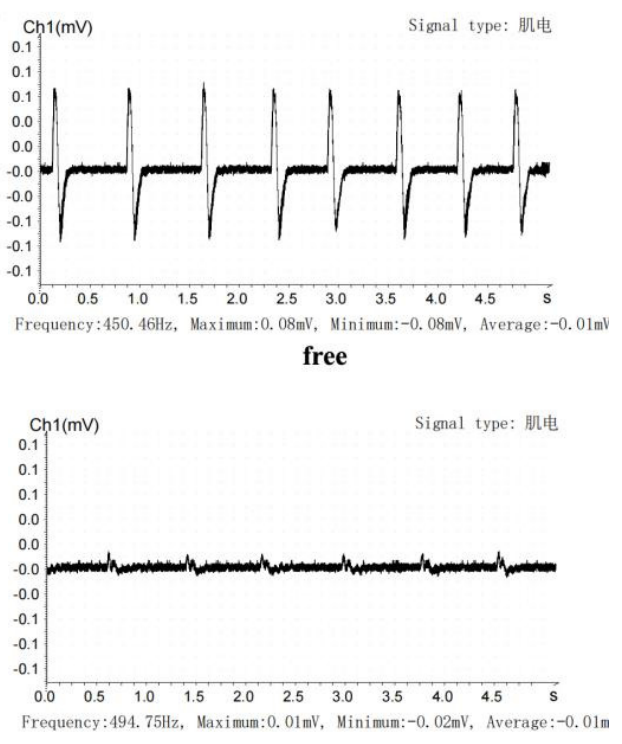

$5 \mu \mathrm{g} / \mu \mathrm{l}$ pethidine hydrochloride

\section{C}

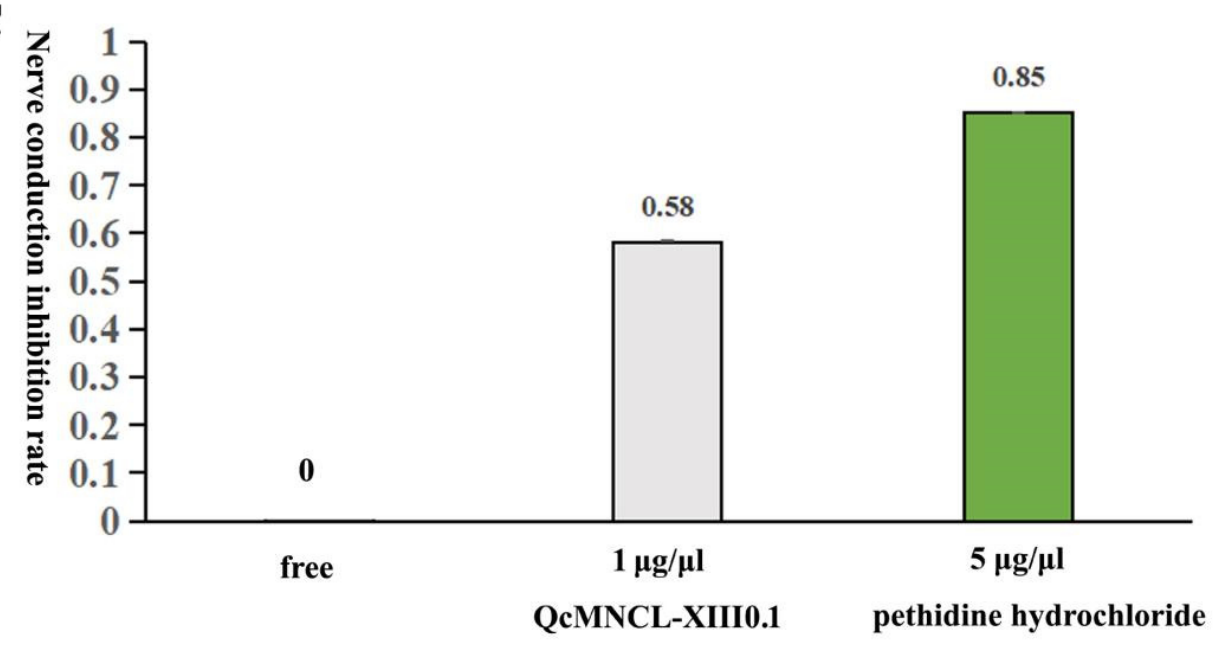

Figure 3. Inhibitory action of QcMNCL-XIII0.1 and on neuromuscular transmission. (A) A total of $1 \mu \mathrm{g} / \mu \mathrm{L}$ of QcMNCL-XIII0.1; (B) a total of $5 \mu \mathrm{g} / \mu \mathrm{L}$ of pethidine hydrochloride (reanalysis from our published data [37]); (C), Nerve conduction inhibition rate of QcMNCL-XIII0.1 and pethidine hydrochloride.

2.3. Construction of Eukaryotic Expression Vector for the CACNA1G Gene and Identification of the Expression of $\alpha 1 G$ Membrane Protein

Conotoxin QcMNCL-XIII0.1 showed a high inhibition rate of neuromuscular conduction, and its application prospects are great; therefore, we further explored its possible 
targets. We chose to investigate whether conotoxin QcMNCL-XIII0.1 could affect the activity of Cav3.1 channels in cell membranes by measuring the changes in intracellular calcium concentration before and after the administration of the toxin.

As described in the Materials and Methods section, the successful construction of the pcDNA3.1-CACNA1G-ceGFP vector (Supplementary Figure S1A) was confirmed by sequencing. The sequence peak diagram is shown in Supplementary Document S2.

Since the three terminals of the CACNA1G vector had a ceGFP fluorescent protein tag, the expression of membrane protein could be observed by ceGFP. Our experimental observations show that the membrane protein $\alpha 1 \mathrm{G}$ was successfully expressed in 293T cells, and fluorescence was observed after $24 \mathrm{~h}$ (Supplementary Figure S1B) and $36 \mathrm{~h}$ (Supplementary Figure S1D). No fluorescence was detected in cells not transfected with the plasmid (Supplementary Figure S1C). The expression of ceGFP was also successfully detected by flow cytometry, and the transfection efficiency was approximately 18\% (Supplementary Figure S1E).

Then, these cell membrane proteins were extracted and assessed by mass spectrometry. The $\alpha 1 G$ membrane protein sequences expressed by CACNA1G were successfully identified by LC-MS/MS to be ALRPDDPPLDGDDADDEGNLSKGER (Figure 4A) and NFGMAFLTLFRVSTGDNWNGIMKDTLR (Figure 4B). In addition, one GFP fluorescent protein tag sequence was successfully identified: GIDFKEDGNILGHK (Figure 4C) and DLKKCYSVEAQSCQR (Figure 4D). Therefore, we successfully expressed the exogenous $\alpha 1 \mathrm{G}$ membrane protein in $293 \mathrm{~T}$ cells.
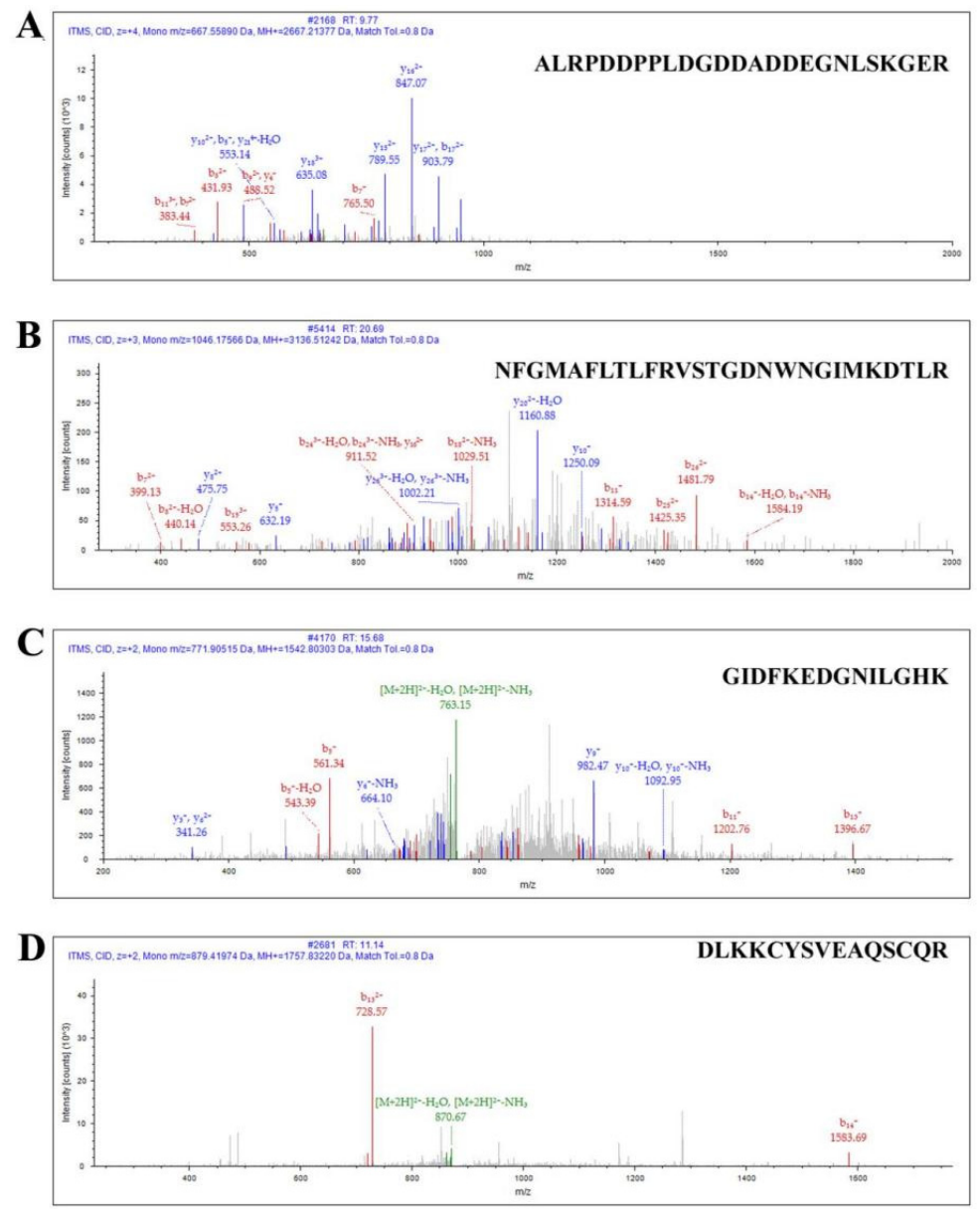

Figure 4. Identification of CACNA1G-ceGFP protein by LC-MS/MS. (A) Ion spectrum of identified sequence: ALRPDDPPLDGDDADDEGNLSKGER; (B) ion spectrum of identified sequence: NFGMAFLTLFRVSTGDNWNGIMKDTLR; (C) ion spectrum of identified sequence of ceGFP: GIDFKEDGNILGHK; (D) ion spectrum of identified sequence of ceGFP: DLKKCYSVEAQSCQR. 


\subsection{Effect of QcMNCL-XIIIO.1 on $\alpha 1 G$ Membrane Proteins}

Fluo-4 AM was used as a fluorescent probe to detect intracellular calcium concentration changes, as it can penetrate the cell membrane and be taken up by cells. These changes in intracellular calcium ion concentration were then measured by flow cytometry. We found that conotoxin QCMNCL-XIII0.1 demonstrated little effect on intracellular calcium ion concentration in 293T cells without plasmid transfection before (Figure 5A) and after administration (Figure 5B), and the fluorescence intensity was basically unchanged or had no significant difference.

A

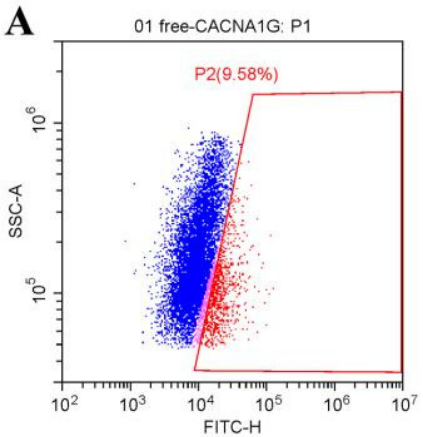

B

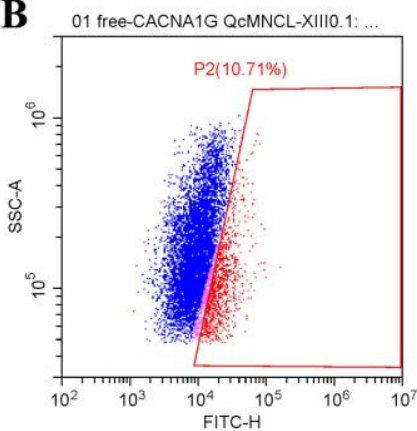

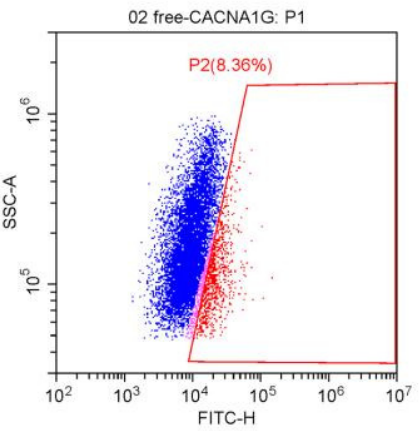
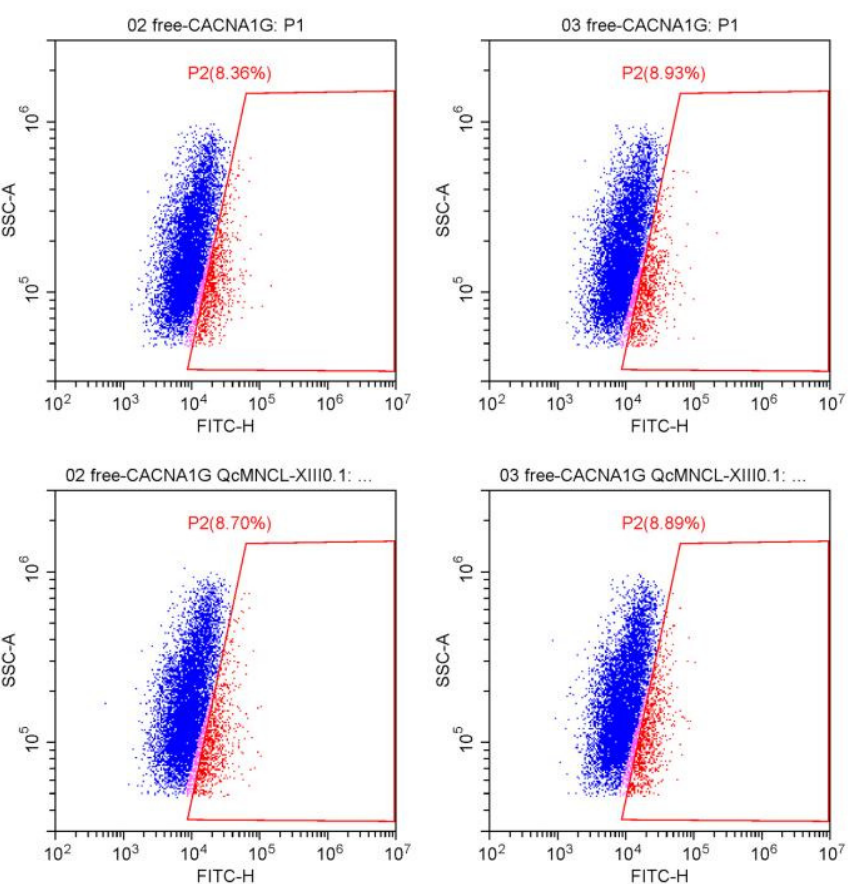

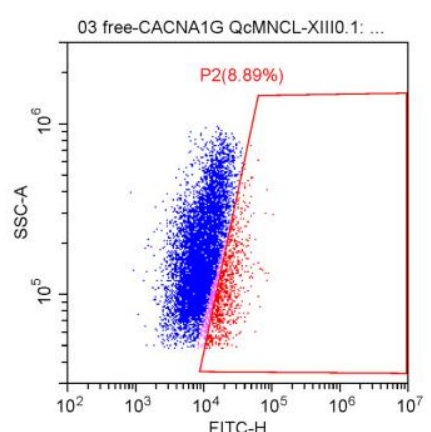

Figure 5. Effect of the fluorescence intensity on free 293T cells without QcMNCL-XIII0.1 or Cav3.1 plasmid: (A) free; (B) recombinant $10 \mathrm{ng} / \mu \mathrm{L}$ QcMNCL-XIIIO.1.

However, after the transfection of $C A C N A 1 G$ with a GFP fluorescent label and the addition of the Fluo-4 fluorescent probe, the fluorescence intensity doubled, indicating that the probe was successfully loaded (Figure 6A). By examining populations of cells before and after the addition of $10 \mathrm{ng} / \mu \mathrm{L}$ conotoxin QcMNCL-XIIIO.1, we found that the percentage inhibition was $(47.18-32.52 \%) / 47.18 \%) * 100 \%$, which was a $31.07 \%$ inhibition compared with the buffer control (Table 1 and Figure $6 \mathrm{~B}$ ). The difference between the D and $\mathrm{E}$ groups was statistically significant, and the $p$-value of the $\mathrm{t}$ test was 0.0238 . This indicated that the conotoxin QcMNCL-XIII0.1 caused the outflow of calcium ions from cells, resulting in a decrease in intracellular calcium ion concentration. We thus speculated that QcMNCL-XIII0.1 directly or indirectly causes intracellular calcium outflow through the T-type calcium channel $\alpha 1 \mathrm{G}$. 
A

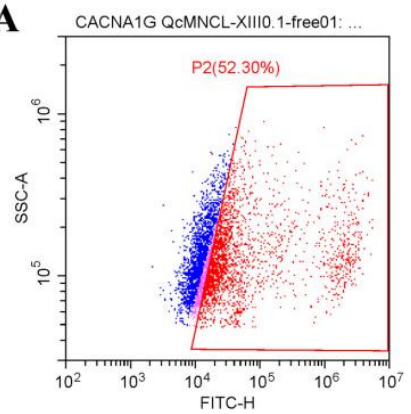

B

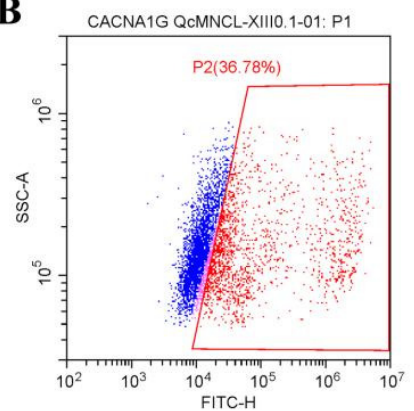

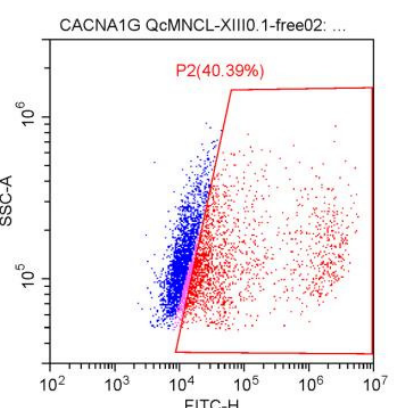
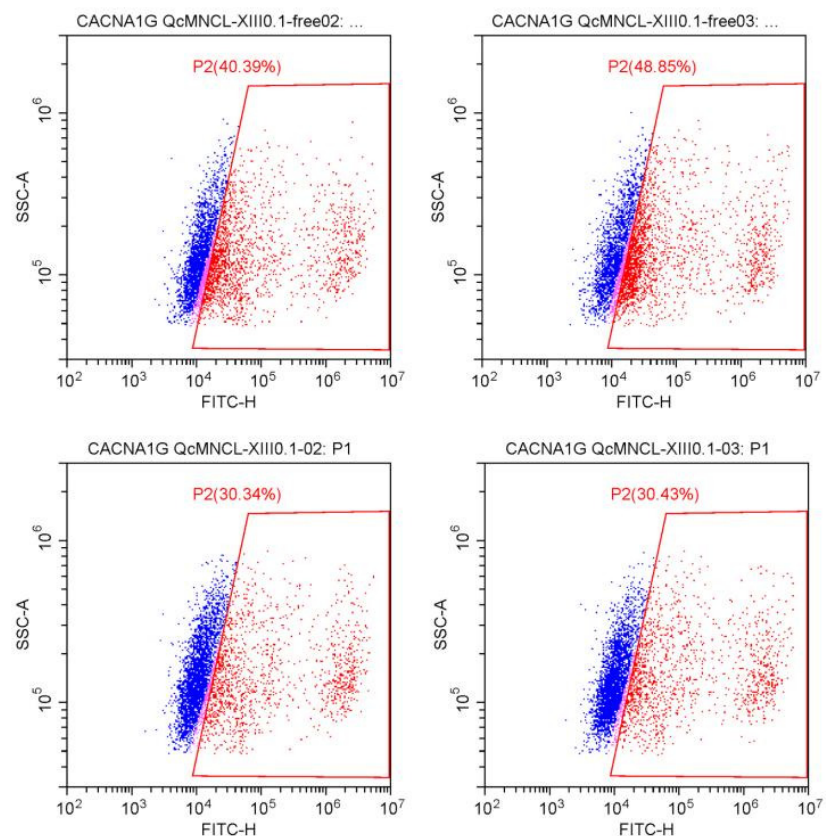

Figure 6. Effect of the fluorescence intensity on free 293T cells after transfection with Cav3.1-ceGFP plasmid: (A) free; (B) recombinant $10 \mathrm{ng} / \mu \mathrm{L}$ QcMNCL-XIII0.1.

Table 1. The fluorescence intensity of 293T cells. Note: A, 293T cells + free + Fluo-4 (Figure 5A); B, 293T cells + free + Fluo-4 + $10 \mathrm{ng} / \mu \mathrm{L}$ QcMNCL-XIII0.1 (Figure 5B); C, 293 T cells transfection with GFP plasmid in $36 \mathrm{~h}$ (Supplementary Figure S1E); D, 293T cells transfection with Cav3.1ceGFP plasmid in $36 \mathrm{~h}+$ Fluo-4 (Figure 6A); E, 293T cells transfection with Cav3.1-ceGFP plasmid in $36 \mathrm{~h}+$ Fluo-4 + $10 \mathrm{ng} / \mu \mathrm{L}$ QcMNCL-XIII0.1 (Figure 6B). In theory, 100\% fluorescence means that the cells detected by flow cytometry were labeled with fluorescent protein ceGFP or Fluo-4.

\begin{tabular}{cccccc}
\hline & A & B & C & D & E \\
\hline & $9.58 \%$ & $10.71 \%$ & $18.26 \%$ & $52.30 \%$ & $36.78 \%$ \\
Average & $8.36 \%$ & $8.70 \%$ & $18.34 \%$ & $40.39 \%$ & $30.34 \%$ \\
Variance & $8.93 \%$ & $8.89 \%$ & $18.95 \%$ & $48.85 \%$ & $30.43 \%$ \\
\hline
\end{tabular}

\section{Discussion}

Although hundreds of conotoxins have been found [5,38-41], very few of them have been successfully prepared and tested for nerve-blocking activity [42-44]. The chemical synthesis of peptides with more than three pairs of disulfide bonds is difficult [45]. After a series of trials, we obtained high purity of the conopeptide QcMNCL-XIIIO.1 by constructing an expression system with the tag TrxA. In the design of an expression vector, we skillfully used the enterokinase with this label for enzyme digestion to facilitate the downstream purification and recovery of the target polypeptide. On average, $5.25 \mathrm{mg}$ of recombinant QcMNCL-XIII0.1 conotoxin was obtained from $1 \mathrm{~L}$ culture. According to the prediction results on the ConoSever, the conotoxin QcMNCL-XIIII0.1 may contain four pairs of disulfide bonds, while the other two conotoxins (k-PVIIA [46] and GeXIV [47]) have only three pairs of disulfide bonds. This may be the key element responsible for the special features of QcMNCL-XIII0.1, such as stability. Animal tests showed that recombinant QcMNCL-XIII0.1 had a strong inhibitory effect on neural signal transduction and nerve conduction inhibition similar to that of anesthetics. The abuse of pethidine-containing drugs is frequently encountered in patients [48]. The conotoxin QcMNCL-XIII0.1, which can block nerve signals at low doses, may become an alternative drug in the future. 
In addition, in analyzing sequence homology on the ConoSever, we found that QcMNCL-XIII0.1 overlaps with the peptide conoCAP-a (a CCAP-related peptide) [49] of the crustacean cardioactive peptide (CCAP) superfamily by $90 \%$, which is a surprising discovery and which provides guidance for further experimentation. Later studies found CCAP to be a multifunctional neuropeptide involved in several physiological processes, such as the release of adipokinetic hormone from the corpora cardiaca and modulating the cardiac ganglion [50,51]. The application of conoCAP-a on rat cardiac myocytes gradually decreased systolic $\mathrm{Ca}^{2+}$ transient amplitude, but conoCAP-a had no effect on L-type $\mathrm{Ca}^{2+}$ channel (LTCC) current and other cell membrane channels and receptors involved in the cardiovascular physiology ( $\beta 1-\mathrm{AR}, \beta 2-\mathrm{AR}, \mathrm{HCN} 1, \mathrm{HCN} 2, \mathrm{Kv} 1.4$, Nav1.5, hERG, V1a, V1b, and V2) [49]. In the pre-experiment, we also tested the cell models transfected with alpha4 nicotinic receptor (CHRNA4), alpha6 nicotinic receptor (CHRNA6), alpha7 nicotinic receptor (CHRNA7), and alpha9 nicotinic receptor (CHRNA9) and found that there was no change evident in the calcium concentration of cells. Therefore, we studied the effect of QcMNCL-XIII0.1 on cells transfected with T-type calcium channel protein. T-type $\mathrm{Ca}^{2+}$ channels play an essential role in the functioning of the nervous system [52]. In addition, T-type calcium channels are a significant etiological factor of pain for a variety of cancers and mainly control and regulate the proliferation, survival, and cell cycle of cancer cells [11,53-61]. However, there are few reports of selective regulators of T-type calcium channel protein Cav3.1 $(\alpha 1 G)$. In the 293T cell model, our experimental results show that the calcium concentration was inhibited by $31.07 \%$ after the QcMNCL-XIII0.1 was added. Our results suggest that the QcMNCL-XIII0.1 maybe interact with Cav3.1 $(\alpha 1 \mathrm{G})$ to inhibit intracellular calcium concentration. Single amino acid variations strongly affect its activity and function [49]. This study focuses on the natural origin of conotoxins, and we will continue to study variants in the future.

In our experiment, Fluo-4 AM was used to compare calcium levels in same populations of cells. Fluo-4 is well suited for photometric and imaging applications that make use of confocal laser scanning microscopy and flow cytometry [62-64]. For the reliability of our experiment, we designated as blank controls groups A and B, and blank group C (Table 1). The continuity of the experimental results preliminarily supports our results. In the future, we may use red or blue fluorescent protein labels for further verification or even a patch clamp experiment.

\section{Conclusions}

We prepared high-purity samples of the conopeptide QcMNCL-XIII0.1 by genetic engineering. Recombinant QcMNCL-XIII0.1 exhibits the ability to block nerve signal transduction in an ex vivo model, similar to that of the anesthetic pethidine hydrochloride. Based on cell flow cytometry, we preliminarily confirmed that the fluorescence was inhibited by $31.07 \%$ in the 293T cell model transfected with Cav3.1, implying the interaction between $\alpha 1 G$ T-type calcium channel protein and recombinant QcMNCL-XIII0.1. The discovery of QcMNCL-XIIII0.1 is conducive to the follow-up study of T-type calcium channel protein Cav3.1 $(\alpha 1 \mathrm{G})$ and promotes its research in the study of pain and in other fields.

\section{Materials and Methods}

\subsection{Construction of Recombinant Expression Vector}

According to the nucleotide sequence of the mature peptide encoded by the conotoxin gene, combined with the multiple cloning site of PET32a (+) vector and the restriction endonuclease site of toxin gene, the codon of the toxin gene was optimized for expression in E. coli. The toxin gene was short, and it was synthesized by direct synthesis. The vector design map is shown in Figure 1. The key steps were as follows: (1) A $50 \mu \mathrm{L}$ enzyme digestion system was used, composed of $1 \mu \mathrm{L}$ of KpnI, $1 \mu \mathrm{L}$ of XhoI, $5 \mu \mathrm{L}$ of $10 \times \mathrm{NEB}$ buffer $1.1,1 \mu \mathrm{g}$ of toxin gene fragment, and $43 \mu \mathrm{L}$ of deionized water. Enzyme digestion at $37^{\circ} \mathrm{C}$ in a constant temperature water bath was performed for $12 \mathrm{~h}$. (2) The $\mathrm{pGEM}^{\circledR}$-T Easy Vector System I was used for plasmid construction (Promega Corporation). The screening 
of engineered strains was performed using $\mathrm{T} 7$ primers, the first generation of clones was sequenced using an ABI3730XL gene sequencer, and positive were clones identified. After the correct construction of the extracted plasmid was confirmed by sequencing, the bacteria were preserved at $-80^{\circ} \mathrm{C}$. (4) Recombinant expression in vitro was performed using strains

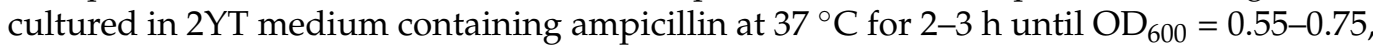
and then, expression was induced by IPTG at $18^{\circ} \mathrm{C}$ for $10 \mathrm{~h}$. We separately collected the uninduced supernatant of BL21 (DE3) cells, the supernatant from BL21 (DE3) cells induced by IPTG after ultrasonification, and the wash protein from $\mathrm{Ni}^{2+}$-chelating sepharose in elution buffer, and all were verified using $12 \%$ sodium dodecyl sulfate polyacrylamide gel electrophoresis (SDS-PAGE) analysis.

\subsection{Purification of Recombinant Conotoxin}

The purification process for recombinant conotoxin was as follows: (1) Single colonies were cultured in $15 \mathrm{~mL}$ of $2 \mathrm{YT}$ medium with shaking at $37^{\circ} \mathrm{C}$ for $12 \mathrm{~h}$ as seed cultures. At a ratio of 1:50, they were inoculated in $1 \mathrm{~L}$ of $2 \mathrm{YT}$ medium and cultured at $37^{\circ} \mathrm{C}$ until the $\mathrm{OD}_{600}$ value reached $0.6-0.7$. At a ratio of $1: 1000,24 \mathrm{mg} / \mathrm{mL}$ of IPTG and $5 \%$ of glucose solution were added, and the cells were cultured at $18^{\circ} \mathrm{C}$ for another $10 \mathrm{~h}$. (2) The bacteria were collected after centrifugation at $4{ }^{\circ} \mathrm{C}$ and $8000 \mathrm{rpm}$ for $10 \mathrm{~min}$. The supernatant was collected after ultrasonication for $1 \mathrm{~h}$ at $4{ }^{\circ} \mathrm{C}$ by centrifugation at $12,000 \mathrm{rpm}$ for $20 \mathrm{~min}$. The fusion toxin polypeptides containing TrxA, a histidine label, and an EK digestion site were isolated by Ni affinity chromatography. (4) The fusion protein solution was passed as $4 \mathrm{~mL}$ through a $3 \mathrm{~K}$ ultrafiltration column and replaced with EK digestion buffer. (5) Then, 1\% EK enzyme with a histidine tag was added, and the proteins were digested at $22{ }^{\circ} \mathrm{C}$ for $18 \mathrm{~h}$. After digestion, the solution was passed through a Ni-affinity chromatography column, the first peak was detected, and the target conotoxin was isolated. The size of the $\mathrm{Ni}^{2+}$-chelating sepharose affinity chromatography column was $1.6 \mathrm{~cm} \times 4 \mathrm{~cm}$. A constant flow rate of $2 \mathrm{~mL} / \mathrm{min}$ was maintained throughout the operation, and a Tris-HCl buffer system was used. The ethanol-sealed $\mathrm{Ni}^{2+}$-chelating sepharose affinity chromatography column was loaded with deionized water, and $0.2 \mathrm{M} \mathrm{NiSO}_{4}$ was loaded to bind the $\mathrm{Ni}^{2+}$ to the column material. Next, we used deionized water to remove the uncombined NiSO4, and this was balanced with an ultrasonic buffer (50mM Tris, $0.5 \mathrm{M} \mathrm{NaCl}$, and $20 \mathrm{mM}$ imidazole, $\mathrm{pH}$ 8.0). The supernatant on the column after ultrasonication was washed with ultrasonic buffer until the UV absorption value reached its baseline, and then, a gradient elution was carried out with a mixture of ultrasonic buffer and elution buffer $(50 \mathrm{mM}$ Tris, $500 \mathrm{mM} \mathrm{NaCl}$, and $500 \mathrm{mM}$ imidazole, $\mathrm{pH} 8.0$ ).

\subsection{Protein Fractionation, Preparation for LC-MS/MS Analysis, and Proteomic Data Analysis}

The LC-MS/MS methods are summarized in our previous articles [37]. The total cell membrane proteins from $293 \mathrm{~T}$ cells were solubilized in lysis buffer (8 M urea, $\mathrm{pH} 8.00$ ) containing $5 \mathrm{mM}$ DTT at $60{ }^{\circ} \mathrm{C}$ for $45 \mathrm{~min}$, followed by alkylation at $25^{\circ} \mathrm{C}$ for $45 \mathrm{~min}$ in the presence of $25 \mathrm{mM}$ iodoacetamide in the dark. The obtained protein solutions were reconstituted in $50 \mathrm{mM}$ ammonium bicarbonate with $0.5 \mathrm{M}$ urea, $\mathrm{pH} 7.8$, and digested (trypsin: protein $=1: 100$ ) for $12 \mathrm{~h}$ at $37^{\circ} \mathrm{C}$. The test time of the total cell membrane proteins was $50 \mathrm{~min}$. The test time of purified recombinant polypeptide sample was $30 \mathrm{~min}$.

\subsection{Bullfrog Sciatic Nerve Bioelectric Activity}

In this experiment, bullfrog sciatic nerve bioelectric activity was used to assess whether the expressed conotoxin had the effect of blocking neuromuscular conduction [65-67]. According to our previous published study [37], animal experimental models were prepared and are shown in the Graphical Abstract of this paper. The tension transducer and the stimulation electrode were connected to a BL-420S biological function experimental system (Chengdu Techman Software Co. Ltd., Chengdu, China). The concentration of conotoxin was $1 \mu \mathrm{g} / \mu \mathrm{L}$. The dosage was $50 \mu \mathrm{L}$. In the calculation of the experimental results, six peaks were collected, and the peak and the trough of each extracted. The peak represents 
the maximum pulling force. Inhibition rate of neural circuit $=$ (value before administrationvalue after administration/value before administration) ${ }^{*} 100 \%$. Value $=$ peak - trough.

\subsection{Construction of pcDNA3.1-CACNA1G-ceGFP Vector}

The cDNA template was donated by the Han Jiahuai Laboratory of Xiamen University. PCR amplification was carried out according to established methods. First, the T easy vector was constructed, and then, the eukaryotic expression vector was constructed. Moreover, $5^{\prime}$-terminal EcoR I and $3^{\prime}$ Not I sites were added.

According to the full-length sequence of the spliced gene, the primers were designed using PREMIER5.0 software and the restriction sites were introduced to construct the eukaryotic expression vector pcDNA3.1-CACNA1G-ceGFP. The sequencing primers used were the T7 promoter (ATTATGCTGAGTGATATCCC) and the SP6 promoter (TAAGATATCACAGTGGATTTA). The full-length primer for the CACNA1G gene was CACNA1G-Up primer (ATGGACGAGGAGGAGGATGGAGC) and CACNA1G-Low (primer GGGGTCCAGGTCTGCTGGGTCAGAGGATAA). We performed PCR product recovery, ligation, transformation, and positive colony screening in turn. Plasmid extraction was performed using the Plasmid Mini prep Kit II kit from Omega Bio-Tek, and monoclonal positive plasmids were extracted according to the manufacturer's instructions. Sequencing of the target gene was performed at Beijing Tsingke Biotechnology Co., Ltd. and Guangzhou IGE Biotechnology Ltd. The obtained sequence was opened by UGENE, saved as an FASTA format document and then assembled using the Seqman module in DNASRAT. The sequence file was modified according to the specific sequence atlas, and then, sequence analysis was carried out.

After the pcDNA3.1-CACNA1G-ceGFP monoclonal recombinant vector was obtained, an endotoxin-free plasmid was extracted using the OMEGA Endo-free Plasmid mini kit (OMEGA) and the specific operation process was carried out according to the manufacturer's instructions.

\subsection{Transient Transfection of Recombinant Plasmid into 293T Cells}

Cell strains were stored in liquid nitrogen. After removal, they were immediately incubated in a $37{ }^{\circ} \mathrm{C}$ water bath and then transferred to DMEM medium containing $10 \%$ fetal bovine serum. Twelve-well plates were used in these experiments. Generally, after 3-4 passages, when the cells were in good condition, they were transfected. Cells were seeded at a cell density of approximately $1 \times 10^{5}$ cells per well. After incubation overnight, the cells were completely adhered to the plates, and the density reached approximately $60-80 \%$; therefore, transfection was carried out. During transfection, in addition to the transfection of the constructed fusion vector, it was also necessary to transfect an empty vector as a blank control. The transfection experiment was carried out according to the Lipofectamine $^{\mathrm{TM}} 3000$ Transfection Reagent (Invitrogen, Carlsbad, CA, USA) instructions.

\subsection{Extraction of Membrane Proteins and Identification by Mass Spectrometry}

Total cell membrane proteins were extracted using the Minute ${ }^{\mathrm{TM}}$ Plasma Membrane Protein Isolation and Cell Fractionation Kit (Invent Biotechnologies, Eden Prairie, MN, USA). The 293T cells cultured for $36 \mathrm{~h}$ after plasmid transfection were used as the experimental group, while untreated 293T cells were used as the blank group to extract the total cell membrane proteins from $5 \times 10^{5} 293 \mathrm{~T}$ cells. Then, mass spectrometry samples from the total cell membrane proteins were prepared for LC-MS/MS.

\subsection{Detection of Intracellular Calcium Concentration by Flow Cytometry}

Preparation of Fluo-4 AM (CAS No.: 273221-67-3) stock liquor was achieved by adding an appropriate amount of $330 \mu \mathrm{L}$ of DMSO to Fluo- 4 AM to prepare $400 \mu \mathrm{M}$ of storage solution that was stored away from light. Fluo-4 AM working solution was made at 1:100, to avoid repeated freeze-thaws. A negative control of just DMSO was used in these experiments. Each experiment was repeated three times. The $293 \mathrm{~T}$ cells were transiently 
transfected for $36 \mathrm{~h}$, the culture medium was removed, and the cells were washed with HBSS solution three times. The Fluo- 4 AM working solution was added to the cells, adding enough to cover the cells, and the cells were incubated at $37{ }^{\circ} \mathrm{C}$ at $5 \% \mathrm{CO}_{2}$ for $45 \mathrm{~min}$. Next, the Fluo-4 AM working solution was removed, and the cells were re-suspended in HBSS solution. The cells were incubated for another $10 \mathrm{~min}$ and gently shaken several times to ensure the complete de-esterification of AM bodies in the cells. The cells were divided into two groups, each with three replicates. The experimental group was treated with $10 \mathrm{ng} / \mu \mathrm{L}$ QcMNCL-XIII0.1, and the control group was treated with the same amount of HBSS, the total amount of which was the same as the volume of QcMNCL-XIIIO.1 added. The cells were placed in $5 \% \mathrm{CO}_{2}$ in the dark at $37{ }^{\circ} \mathrm{C}$ for $1 \mathrm{~min}$. The cells were then immediately assessed by flow cytometry. The excitation wavelength was $494 \mathrm{~nm}$, and the emission wavelength was $516 \mathrm{~nm}$. This spectrum basically overlaps with that of FITC, so the spectrum detection channel was set as FITC. A total of 10,000 cells were collected: 5000 cells were collected both before and after administration. The intracellular calcium concentration was expressed as the average fluorescence, and the rate of change in fluorescence was calculated. The percentage inhibition of the fluorescence change rate $=($ administration group - control group $) /$ administration group $\times 100 \%$.

Supplementary Materials: The following supporting information can be downloaded at: https: / / www.mdpi.com/article/10.3390/toxins14020099/s1, Supplementary Figure S1: The 293T cells transfected with pcDNA3.1-CACNA1G-ceGFP detected by GFP fluorescence microscopy. (A) The map of pcDNA3.1-CACNA1G-ceGFP; (B) fluorescence microscopic observation after $24 \mathrm{~h}$; (C) positive control group; (D) fluorescence microscopic observation after $36 \mathrm{~h}$; (E) flow cytometry fluorescence detection after $36 \mathrm{~h}$. Supplementary Document S1: Sanger sequencing of QcMNCL-XIII0.1 gene. Supplementary Document S2: Sanger sequencing of CACNA1G gene.

Author Contributions: H.Z. conceived of the presented idea, supported by X.P., H.Z. and A.L. performed the experiments and analyzed the data. H.Z. and X.P. drafted and revised the manuscripts. All authors discussed the results and contributed to the final manuscript. All authors have read and agreed to the published version of the manuscript.

Funding: This work is supported by National Natural Science Foundation of China (81770173), Natural Science Foundation of Guangdong Province (Major Basic Cultivation Project 2018B030308004, and Major Projects of Basic and Applied Basic Research 2019B1515120033), and Pearl River Talents Program Local Innovative and Research Teams (2017BT01S131).

Institutional Review Board Statement: Not applicable.

Informed Consent Statement: Not applicable.

Data Availability Statement: Not applicable.

Conflicts of Interest: The authors declare no conflict of interest.

\section{References}

1. Bandyopadhyay, P.K.; Colledge, C.J.; Walker, C.S.; Zhou, L.M.; Hillyard, D.R.; Olivera, B.M. Conantokin-G Precursor and Its Role in Gamma-Carboxylation by a Vitamin K-Dependent Carboxylase from a Conus Snail. J. Biol. Chem. 1998, 273, 5447-5450. [CrossRef]

2. Conticello, S.G.; Kowalsman, N.D.; Jacobsen, C.; Yudkovsky, G.; Sato, K.; Elazar, Z.; Petersen, C.M.; Aronheim, A.; Fainzilber, M. The Prodomain of a Secreted Hydrophobic Mini-Protein Facilitates Its Export from the Endoplasmic Reticulum by Hitchhiking on Sorting Receptors. J. Biol. Chem. 2003, 278, 26311-26314. [CrossRef] [PubMed]

3. Chen, J.; Liang, L.; Ning, H.; Cai, F.; Liu, Z.; Zhang, L.; Zhou, L.; Dai, Q. Cloning, Synthesis and Functional Characterization of a Novel A-Conotoxin Lt1.3. Mar. Drugs 2018, 16, 112. [CrossRef] [PubMed]

4. Kaas, Q.; Westermann, C.; Craik, D.J. Conopeptide Characterization and Classifications: An Analysis Using Conoserver. Toxicon 2010, 55, 1491-1509. [CrossRef] [PubMed]

5. Tayo, L.L.; Lu, B.; Cruz, L.J.; Yates, J.R., III. Proteomic Analysis Provides Insights on Venom Processing in Conus Textile. J. Proteome Res. 2010, 9, 2292-2301. [CrossRef]

6. Craig, A.G.; Norberg, T.; Griffin, D.; Hoeger, C.; Akhtar, M.; Schmidt, K.; Low, W.; Dykert, J.; Richelson, E.; Navarro, V.; et al. Contulakin-G, an O-Glycosylated Invertebrate Neurotensin. J. Biol. Chem. 1999, 274, 13752-13759. [CrossRef] 
7. Allen, J.W.; Hofer, K.; McCumber, D.; Wagstaff, J.D.; Layer, R.T.; McCabe, R.T.; Yaksh, T.L. An Assessment of the Antinociceptive Efficacy of Intrathecal and Epidural Contulakin-G in Rats and Dogs. Anesth. Analg. 2007, 104, 1505-1513. [CrossRef]

8. Robinson, S.D.; Norton, R.S. Conotoxin Gene Superfamilies. Mar. Drugs 2014, 12, 6058-6101. [CrossRef]

9. Adams, D.J.; Berecki, G. Mechanisms of Conotoxin Inhibition of N-Type (Ca(V)2.2) Calcium Channels. Biochim. Biophys. Acta 2013, 1828, 1619-1628. [CrossRef]

10. Todorovic, S.M.; Jevtovic-Todorovic, V. Targeting of Cav3.2 T-Type Calcium Channels in Peripheral Sensory Neurons for the Treatment of Painful Diabetic Neuropathy. Pflugers Arch. 2014, 466, 701-706. [CrossRef]

11. Dziegielewska, B.; Gray, L.S.; Dziegielewski, J. T-Type Calcium Channels Blockers as New Tools in Cancer Therapies. Pflugers Arch. 2014, 466, 801-810. [CrossRef] [PubMed]

12. Bourinet, E.; Francois, A.; Laffray, S. T-Type Calcium Channels in Neuropathic Pain. Pain 2016, 157 (Suppl. 1), S15-S22. [CrossRef] [PubMed]

13. Yang, M.; Zhou, M. M-Conotoxin Tsiiia, a Peptide Inhibitor of Human Voltage-Gated Sodium Channel Hna(V)1.8. Toxicon 2020, 186, 29-34. [CrossRef] [PubMed]

14. Lewis, R.J.; Dutertre, S.; Vetter, I.; Christie, M.J. Conus Venom Peptide Pharmacology. Pharmacol. Rev. 2012, 64, 259-298. [CrossRef]

15. Wermeling, D.P. Ziconotide, an Intrathecally Administered N-Type Calcium Channel Antagonist for the Treatment of Chronic Pain. Pharmacotherapy 2005, 25, 1084-1094. [CrossRef]

16. Sun, Z.; Zhangsun, M.; Dong, S.; Liu, Y.; Qian, J.; Zhangsun, D.; Luo, S. Differential Expression of Nicotine Acetylcholine Receptors Associates with Human Breast Cancer and Mediates Antitumor Activity of Ao-Conotoxin Gexiva. Mar. Drugs 2020, 18, 61. [CrossRef]

17. Essack, M.; Bajic, V.B.; Archer, J.A. Conotoxins That Confer Therapeutic Possibilities. Mar. Drugs 2012, 10, 1244-1265. [CrossRef]

18. Han, T.S.; Teichert, R.W.; Olivera, B.M.; Bulaj, G. Conus Venoms-A Rich Source of Peptide-Based Therapeutics. Curr. Pharm. Des. 2008, 14, 2462-2479. [CrossRef]

19. Malmberg, A.B.; Gilbert, H.; McCabe, R.T.; Basbaum, A.I. Powerful Antinociceptive Effects of the Cone Snail Venom-Derived Subtype-Selective Nmda Receptor Antagonists Conantokins G and T. Pain 2003, 101, 109-116. [CrossRef]

20. Perez-Reyes, E. Molecular Characterization of T-Type Calcium Channels. Cell Calcium 2006, 40, 89-96. [CrossRef]

21. Catterall, W.A. Structure and Regulation of Voltage-Gated Ca2+ Channels. Annu. Rev. Cell Dev. Biol. 2000, 16, 521-555. [CrossRef] [PubMed]

22. Todorovic, S.M.; Jevtovic-Todorovic, V. The Role of T-Type Calcium Channels in Peripheral and Central Pain Processing. CNS Neurol. Disord. Drug Targets 2006, 5, 639-653. [CrossRef] [PubMed]

23. Guéguinou, M.; Chantôme, A.; Fromont, G.; Bougnoux, P.; Vandier, C.; Potier-Cartereau, M. Kca and Ca(2+) Channels: The Complex Thought. Biochim. Biophys. Acta 2014, 1843, 2322-2333. [CrossRef]

24. Wang, D.; Ragnarsson, L.; Lewis, R.J. T-Type Calcium Channels in Health and Disease. Curr. Med. Chem. 2020, 27, 3098-3122. [CrossRef] [PubMed]

25. Kaur, S.; Maslov, L.N.; Singh, N.; Jaggi, A.S. Dual Role of T-Type Calcium Channels in Anxiety-Related Behavior. Chem. Rev. 2019, 31. [CrossRef] [PubMed]

26. Ertel, E.A.; Campbell, K.P.; Harpold, M.M.; Hofmann, F.; Mori, Y.; Perez-Reyes, E.; Schwartz, A.; Snutch, T.P.; Tanabe, T.; Birnbaumer, L.; et al. Nomenclature of Voltage-Gated Calcium Channels. Neuron 2000, 25, 533-535. [CrossRef]

27. Muth, J.N.; Varadi, G.; Schwartz, A. Use of Transgenic Mice to Study Voltage-Dependent Ca2+ Channels. Trends Pharmacol. Sci. 2001, 22, 526-532. [CrossRef]

28. Stotz, S.C.; Zamponi, G.W. Structural Determinants of Fast Inactivation of High Voltage-Activated Ca(2+) Channels. Trends Neurosci. 2001, 24, 176-181. [CrossRef]

29. Zamponi, G.W.; Lewis, R.J.; Todorovic, S.M.; Arneric, S.P.; Snutch, T.P. Role of Voltage-Gated Calcium Channels in Ascending Pain Pathways. Brain Res. Rev. 2009, 60, 84-89. [CrossRef]

30. Kuo, I.Y.; Hill, C.E. Measuring T-Type Calcium Channel Currents in Isolated Vascular Smooth Muscle Cells. Methods Mol. Biol. 2017, 1527, 189-200.

31. Fan, G.; Cui, Y.; Gollasch, M.; Kassmann, M. Elementary Calcium Signaling in Arterial Smooth Muscle. Channels 2019, 13, 505-519. [CrossRef] [PubMed]

32. Talley, E.M.; Cribbs, L.L.; Lee, J.H.; Daud, A.; Perez-Reyes, E.; Bayliss, D.A. Differential Distribution of Three Members of a Gene Family Encoding Low Voltage-Activated (T-Type) Calcium Channels. J. Neurosci. 1999, 19, 1895-1911. [CrossRef] [PubMed]

33. Feltz, A. Low-Threshold-Activated Ca Channels: From Molecules to Functions: Over 25 Years of Progress. Crit. Rev. Neurobiol. 2006, 18, 169-178. [CrossRef]

34. Zhang, J.; Shi, Q.; Gong, Q.; Wen, X.; Li, H.; He, J.; Wang, Y.; Wu, H.; Wang, H.; Wang, X. Up-Regulation of Cav3.1 Expression in Sh-Sy5y Cells Induced by Lidocaine Hydrochloride. Artif. Cells Nanomed. Biotechnol. 2018, 46 (Suppl. 1), 372-379.

35. Snutch, T.P.; Zamponi, G.W. Recent Advances in the Development of T-Type Calcium Channel Blockers for Pain Intervention. Br. J. Pharmacol. 2018, 175, 2375-2383. [CrossRef]

36. Terlau, H.; Weiss, N.; Zamponi, G.W. T-Type Calcium Channels: From Molecule to Therapeutic Opportunities. Proc. Natl. Acad. Sci. USA 2019, 108, 34-39.

37. Zhang, H.; Wang, L.; Yang, X.; Lian, Z.; Qiu, Y.; Dong, Z.; Wu, X.; Pan, X. Identification of Novel Conopeptides and Distinct Gene Superfamilies in the Marine Cone Snail Conus Quercinus. Front. Mar. Sci. 2021, 8, 766792. [CrossRef] 
38. Lu, A.; Yang, L.; Xu, S.; Wang, C. Various Conotoxin Diversifications Revealed by a Venomic Study of Conus Flavidus. Mol. Cell. Proteom. 2014, 13, 105-118. [CrossRef]

39. Zhang, H.; Fu, Y.; Wang, L.; Liang, A.; Chen, S.; Xu, A. Identifying Novel Conopepetides from the Venom Ducts of Conus Litteratus through Integrating Transcriptomics and Proteomics. J. Proteom. 2019, 192, 346-357. [CrossRef]

40. Vetter, I.; Lewis, R.J. Therapeutic Potential of Cone Snail Venom Peptides (Conopeptides). Curr. Top. Med. Chem. 2012, 12, 1546-1552. [CrossRef]

41. Wilson, D.T.; Bansal, P.S.; Carter, D.A.; Vetter, I.; Nicke, A.; Dutertre, S. Characterisation of a Novel a-Superfamily Conotoxin Biomedicines 2020, 8, 128. [CrossRef] [PubMed]

42. Dao, F.Y.; Yang, H.; Su, Z.D.; Yang, W.; Wu, Y.; Hui, D.; Chen, W.; Tang, H.; Lin, H. Recent Advances in Conotoxin Classification by Using Machine Learning Methods. Br. J. Pharmacol. 2017, 22, 1057. [CrossRef] [PubMed]

43. Jin, A.H.; Muttenthaler, M. Conotoxins: Chemistry and Biology. Chem. Rev. 2019, 119, 11510-11549. [CrossRef] [PubMed]

44. Gao, B.; Peng, C.; Yang, J.; Yi, Y.; Zhang, J.; Shi, Q. Cone Snails: A Big Store of Conotoxins for Novel Drug Discovery. Toxins 2017, 9, 397. [CrossRef]

45. Heimer, P.; Schmitz, T.; Bäuml, C.A.; Imhof, D. Synthesis and Structure Determination of $\mu$-Conotoxin Piiia Isomers with Different Disulfide Connectivities. J. Vis. Exp. 2018, 58368. [CrossRef]

46. Kwon, S.; Bosmans, F.; Kaas, Q.; Cheneval, O.; Conibear, A.C.; Rosengren, K.J.; Wang, C.K.; Schroeder, C.I.; Craik, D.J. Efficient Enzymatic Cyclization of an Inhibitory Cystine Knot-Containing Peptide. Biotechnol. Bioeng. 2016, 113, 2202-2212. [CrossRef]

47. Zhangsun, D.; Zhu, X.; Kaas, Q.; Wu, Y.; Craik, D.J.; McIntosh, J.M.; Luo, S. Ao-Conotoxin Gexiva Disulfide Bond Isomers Exhibit Differential Sensitivity for Various Nicotinic Acetylcholine Receptors but Retain Potency and Selectivity for the Human A9 $\alpha 10$ Subtype. Neuropharmacology 2017, 127, 243-252. [CrossRef]

48. Kul, A.; Ozdemir, M.; Sagirli, O. Determination of Pethidine of Abuse and Relevant Metabolite Norpethidine in Urine by Ultra-Performance Liquid Chromatography-Tandem Mass Spectrometry. J. Pharm. Biomed. Anal. 2020, 186, 113320. [CrossRef]

49. Möller, C.; Melaun, C.; Castillo, C.; Díaz, M.E.; Renzelman, C.M.; Estrada, O.; Kuch, U.; Lokey, S.; Marí, F. Functional Hypervariability and Gene Diversity of Cardioactive Neuropeptides. J. Biol. Chem. 2010, 285, 40673-40680. [CrossRef]

50. Veelaert, D.; Passier, P.; Devreese, B.; Vanden Broeck, J.; Van Beeumen, J.; Vullings, H.G.; Diederen, J.H.; Schoofs, L.; De Loof, A. Isolation and Characterization of an Adipokinetic Hormone Release-Inducing Factor in Locusts: The Crustacean Cardioactive Peptide. Endocrinology 1997, 138, 138-142. [CrossRef]

51. Cruz-Bermúdez, N.D.; Marder, E. Multiple Modulators Act on the Cardiac Ganglion of the Crab, Cancer Borealis. J. Exp. Biol. 2007, 210 Pt 16, 2873-2884. [CrossRef] [PubMed]

52. Giordanetto, F.; Knerr, L.; Wållberg, A. T-Type Calcium Channels Inhibitors: A Patent Review. Expert Opin. Ther. Pat. 2011, 21, 85-101. [CrossRef] [PubMed]

53. Kerckhove, N.; Mallet, C.; François, A.; Boudes, M.; Chemin, J.; Voets, T.; Bourinet, E.; Alloui, A.; Eschalier, A. Ca(V)3.2 Calcium Channels: The Key Protagonist in the Supraspinal Effect of Paracetamol. Pain 2014, 155, 764-772. [CrossRef]

54. Leventhal, D.K.; Gage, G.J.; Schmidt, R.; Pettibone, J.R.; Case, A.C.; Berke, J.D. Basal Ganglia Beta Oscillations Accompany Cue Utilization. Neuron 2012, 73, 523-536. [CrossRef]

55. Antal, L.; Martin-Caraballo, M. T-Type Calcium Channels in Cancer. Cancers 2019, 11, 134. [CrossRef]

56. Taylor, J.T.; Zeng, X.B.; Pottle, J.E.; Lee, K.; Wang, A.R.; Yi, S.G.; Scruggs, J.A.; Sikka, S.S.; Li, M. Calcium Signaling and T-Type Calcium Channels in Cancer Cell Cycling. World J. Gastroenterol. 2008, 14, 4984-4991. [CrossRef]

57. Barceló, C.; Sisó, P.; Maiques, O.; de la Rosa, I.; Martí, R.M. T-Type Calcium Channels: A Potential Novel Target in Melanoma Mar. Drugs 2020, 12, 391. [CrossRef]

58. Huang, W.; Lu, C.; Wu, Y.; Ouyang, S.; Chen, Y. T-Type Calcium Channel Antagonists, Mibefradil and Nnc-55-0396 Inhibit Cell Proliferation and Induce Cell Apoptosis in Leukemia Cell Lines. J. Exp. Clin. Cancer Res. 2015, 34, 54. [CrossRef]

59. Dziegielewska, B.; Casarez, E.V.; Yang, W.Z.; Gray, L.S.; Dziegielewski, J.; Slack-Davis, J.K. T-Type Ca2+ Channel Inhibition Sensitizes Ovarian Cancer to Carboplatin. Mol. Cancer Ther. 2016, 15, 460-470. [CrossRef]

60. Matsunami, M.; Kirishi, S.; Okui, T.; Kawabata, A. Chelating Luminal Zinc Mimics Hydrogen Sulfide-Evoked Colonic Pain in Mice: Possible Involvement of T-Type Calcium Channels. Neuroscience 2011, 181, 257-264. [CrossRef]

61. Chen, J.; Liu, X.; Yu, S.; Liu, J.; Chen, R.; Zhang, Y.; Jiang, L.; Dai, Q. A Novel $\Omega$-Conotoxin Bu8 Inhibiting N-Type Voltage-Gated Calcium Channels Displays Potent Analgesic Activity. Acta Pharm. Sin. B 2021, 11, 2685-2693. [CrossRef] [PubMed]

62. Sato, M.; Adachi, T.; Tsubata, T. Augmentation of Signaling through Bcr Containing Ige but Not That Containing Iga Due to Lack of Cd22-Mediated Signal Regulation. J. Immunol. 2007, 178, 2901-2907. [CrossRef] [PubMed]

63. Paredes, R.M.; Etzler, J.C.; Watts, L.T.; Wei, Z.; Lechleiter, J.D. Chemical Calcium Indicators. Methods 2008, 46, 143-151. [CrossRef] [PubMed]

64. Patel, D.; Peng, R.; Guo, H.; Lin, R.; Zhao, Q.; Liao, J.; Diwu, Z. A Highly Selective Fluorescent Probe for the Intracellular Measurement of Magnesium Ion. Anal. Biochem. 2020, 609, 113910. [CrossRef]

65. Pexton, T.; Moeller-Bertram, T.; Schilling, J.M.; Wallace, M.S. Targeting Voltage-Gated Calcium Channels for the Treatment of Neuropathic Pain: A Review of Drug Development. Expert Opin. Investig. Drugs 2011, 20, 1277-1284. [CrossRef] 
66. Cymerman, A.; Gottlieb, S.F. Effects of Increased Oxygen Tensions on Bioelectric Properties of Frog Sciatic Nerve. Aerosp. Med. 1970, 41, 36-39.

67. Gaffey, C.T.; Tenforde, T.S. Bioelectric Properties of Frog Sciatic Nerves during Exposure to Stationary Magnetic Fields. Radiat. Environ. Biophys. 1983, 22, 61-73. [CrossRef] 